УДК 371.315

DOI: $\underline{10.35619 / \text { iiu.v1i13.368 }}$

Oleksandr Fedoryshyn

Candidate of Pedagogical Sciences, Professor of Practice of English Language Department, Rivne State University for the Humanities,

Rivne, Ukraine

ORCID: 0000-0003-0731-0186

e-mail: ofedoryshin@gmail.com

Viktoriia Fedoryshyna

Bilingual Membership Records Assistant,

Ontario College of Teachers,

Ontario, Canada

ORCID: 0000-0001-7303-6926

e-mail:vfedoryshyna@oct.ca

\title{
DISTANCE EDUCATION IN CANADA: BEGINNINGS, EARLY AND RECENT DEVELOPMENTS
}

\begin{abstract}
The COVID-19 pandemic has had a huge impact on educational systems worldwide, leading to the near-total closures of schools, universities and colleges. Most governments decided to temporarily close educational institutions to reduce the spread of Coronavirus. Millions of students are having their education disrupted. Efforts to slow it through non-pharmaceutical interventions and preventive measures such as social distancing and selfisolation have prompted the widespread closure of primary, secondary, and tertiary schooling in over 100 countries.

In the sphere of education, many of the measures that countries have adopted in response to the crisis are related to the suspension of face-to-face classes at all levels, which has given rise to three main areas of action: the deployment of distance learning modalities through a variety of formals and platforms (which or without the use of technology); the support and mobilization of education personnel and communities; and concern for the health and overall well-being of students.

In the article developments of education in Canada are considered. The measures taken by the country are the same as in other countries of the world, but the development and implementation of governmental and educational programs for every level and their interaction between institutions, students and their parents are accentuated there. The government cooperates with various organizations (governmental and nongovernmental) trying to provide schools, universities and colleges with all necessary for distance learning, and, firstly, access to modern technology and the Internet.
\end{abstract}

(C) Oleksandr Fedoryshyn,

Viktoriia Fedoryshyna, 2021 
Distance education as a form of learning appeared long ago. But nowadays it has a new challenge to be activated mandatory, other than traditional methods of gaining knowledge should be implemented involving advanced technology.

Keywords: COVID-19 pandemic, social distancing, self-isolation, distance education, online learning, hardware, software, face-to-face classes, learning environment.

Problem statement. COVID-19 as a global pandemic was declared by the World Health Organization on March 11, 2020. The disease has dramatically changed lives throughout the world and raised the problem of new interactions between people. Most governments around the world authorized unprecedented social containment measures to eliminate the worst consequences of the disease. These measures among others required social distancing and temporary physical closure of educational institutions. In education, the pandemic has caused a shift away from traditional classroom teaching model. It has changed education forever.

It has resulted in schools closures all over the world. Education has changed dramatically, with the distinctive rise of e-learning, whereby teaching is undertaken remotely on digital platforms.

While countries are at different points in their COVID-19 infection rates, worldwide there are currently more than 1.2 billion children in 186 countries affected by school closures due to the pandemic (refers to learners enrolled at pre-primary, primary, lower-secondary, and upper-secondary levels of education, as well as at tertiary education level (UNESCO, 2020).

Online learning has become a widespread method for providing education at all levels. It requires new modes of presentation and interaction. The contribution of this study is to evaluate the learners' new experience in online education and to assess the feasibility of the virtual methods of learning.

Research publications analysis. Distance education or distance learning commonly refers to formal education offerings where instructor and learner are physically separated and where learners can appropriately design materials at a place, time and pace of their choosing. Today most distance learning involves some form of communications technology to link learner to instructor and other learners.

\begin{tabular}{|c|l|l|}
\hline & \multicolumn{1}{|c|}{ Advantages } & \multicolumn{2}{|c|}{ Disadvantages } \\
\hline 1. & $\begin{array}{l}\text { Ability to combine work with } \\
\text { exiting commitments }\end{array}$ & $\begin{array}{l}\text { Distance learning requires self- } \\
\text { motivation }\end{array}$ \\
\hline 2. & Cheaper & $\begin{array}{l}\text { Lack of face-to-face time in virtual } \\
\text { learning }\end{array}$ \\
\hline 3. & No deadlines & $\begin{array}{l}\text { Distance learning does not offer } \\
\text { immediate feedback }\end{array}$ \\
\hline 4. & Less pressure & Distance learning must be accredited \\
\hline 5. & No set start date & $\begin{array}{l}\text { Distance learning does give students the } \\
\text { opportunity to work on oral } \\
\text { communication skills }\end{array}$ \\
\hline
\end{tabular}




\begin{tabular}{|l|l|l|}
\hline 6. & $\begin{array}{l}\text { You can decide your time of } \\
\text { and place of study }\end{array}$ & $\begin{array}{l}\text { Distance learning does not always offer } \\
\text { all the necessary courses online }\end{array}$ \\
\hline 7. & $\begin{array}{l}\text { No matter where you live }- \\
\text { you can still achieve a degree } \\
\text { from anywhere in the world }\end{array}$ & $\begin{array}{l}\text { Distance learning requires you to you to } \\
\text { have constant, reliable, access to } \\
\text { technology }\end{array}$ \\
\hline
\end{tabular}

Forms of distance education provide learning experiences for students to access education from remote locations or who, for various reasons, cannot attend a school, vocational college, or university. Distance education addresses issues related to geographical distance but also for many other reasons which prevent in-person attendance at classes (Hrastinski, 2008; Moore, 2011; Singh \& Thurman, 2019).

Online learning experiences through distance education can be either asynchronous or synchronous. Asynchronous learning occurs when students can choose their own time for participation in learning through different media tools. Accordingly, timing - logging in at own time, learning at own pace; communication - posting responses to activities, reading and writing feedback; tools - E-mail, discussion board; role of a teacher - to set up discussion boards, and to be a facilitator between students. Synchronous learning activities occur through live videos or audio conferencing with immediate feedback. Accordingly, timing - logging in at the same time; communication - face-toface interactions, talking back/forth within a group; tools - video or audio tool; role of a teacher - as an instructor and interacting with students (Hrastinski, 2008).

That is, when distance learning courses include some on-site instruction, they are referred to as blended or hybrid courses. When they have no set entrance requirements they are referred to as open learning courses.

Educational institutions had to adopt a digital approach to learning process, dramatically transitioning conventional in-person classroom learning to predominantly distance learning. Distance learning or distance education, elearning, mobile learning, or online learning, is a form of education where there is separation of teachers from students during the instruction and learning process (Berg \& Simonson, 2016) it is also an instructional practice that effectively utilizes a wide range of tools and technology to enrich the student learning experience (Klein, 2016) and to facilitate student-faculty and studentstudent communication. (Berg \& Simonson, 2016) Online learning can be termed as a tool that can make the teaching-learning process more studentcentered, more innovative, and even more flexible. Online learning is defined as "learning experiences in synchronous or asynchronous environments using different devices (e.g., mobile phones, laptops, etc.) with internet access. In these environments, students can be anywhere (independent) to learn and interact with instructors and other students". (Singh \& Thurman, 2019).

The minimum technological requirements for successful distance learning include the acquisition of hardware such as a computer, mobile device (cellular phones), or webcam, some form of listening device, videoconferencing 
applications such as WebEx, Zoom, Microsoft Windows or Apple operating systems, and a stable internet connection with a great speed.

In many countries of the world, educators worry about the pandemic, investigating the most effective ways to create online platforms in education. The traditional delivery of teacher education programs in classrooms may need to be considered with new ways, new skills and knowledge students may need in the future.

The research aims and objectives are to analyze the adoption and possibility of distance education in Canada.

Presenting the main research material. Correspondence education, the initial form of distance education, developed in the mid-nineteenth century in Europe and then spread to the United States and so on. Initially, distance education used the finest technology available at that time, the postal system, to open educational prospects to people who wanted to study but were not able to attend traditional schools. People who gained most from correspondence education were women, professional people, physical disabled, and individuals who lived in areas where schools did not exist. Isaac Pitman, a British is attributed to pioneering the concept of "distance education". He started by teaching shorthand via correspondence in 1840. Students were asked to copy passages from Bible and send them for grading via the new penny post system.

In America, distance education began in 1874 at Illinois Wesleyan University where bachelor and graduate degrees could be obtained without being present in the classes. The Chautauqua movement in the year 1882 gave the much-required thrust to correspondence education. Correspondence education became quite famous by 1900 and problems of excellence and fair practice came with the popularity. The National Home Study Council (NHSC) was formed in 1926 in part to deal with such issues. Distance education went through a major change after the invention of radio in the 1920s and the arrival of television in the 1940s. Distance education is increasingly using combinations of different technologies to improve communication between teachers and students. In 1900, after the arrival of computer, distance education took a big leap. Now the teachers and students can converse sitting face-to-face.

In Canada, it was used first in 1889 to provide degree opportunities for rural teachers who were unable to attend McGill University full time. By 1912, the Universities of Saskatchewan and Alberta were offering off-campus self-study programs for rural learners. In 1921, a parent wrote the BC Ministry of Education requesting study materials for his children because they were too far from a school, and at first primary and then secondary correspondence education was begun. As the provision of schooling across Canada changed, the need for correspondence materials, especially at the primary grades, decreased. However, secondary course materials were always in demand. Today most provinces continue to develop and offer k-12 distance education programming.

Although the first developments in distance learning were mainly printbased, Canada was an early adopter of new technologies for adult learning. In 1941 the CBC, the Canadian Association for Adult Education and the Federation 


\section{Інноватика у вихованні. Випуск 13.Том 1. 2021.}

of Agriculture together initiated Farm Radio Forum. The series of radio broadcasts and materials for living room study groups were coordinated by St Francis Xavier University in cooperation with universities across the country. The National Film Board of Canada with its local community presentations and associated discussions was another initiative.

The 1960s brought increasing demand for further education and more universities began technology-based programs. Memorial University was famous for the use of slow-scan video to provide a consulting service to doctors in remote communities. This led to the development of an extensive number of audio- and then video-conferencing sites that were used for k-12 and adult education. To meet the needs of co-op students on worksite placements in remote locations the University of Waterloo instituted audiotaped lectures with accompanying text and assignments.

In the 1970s, with greater recognition of the possibilities of distance education, provincial governments moved to establish three institutions focused solely on distance education. In 1972, the Alberta government instituted Athabasca University (AU), which offered courses in arts and science and had an "open" entry system. Modeled on the British Open University, AU relied on print course materials and student-tutor interaction via phone. In Québec, Téléuniversité was established to offer university credit and noncredit courses throughout the province. British Columbia established the Open Learning Institute (OLI) in 1978 to provide college, adult basic and technical, career, vocational and university education to students throughout the province.

Knowledge Network, the telecommunications arm of OLI, was established in 1980 after a highly successful initiative of the federal and provincial governments with the ANIK B satellite. Soon other telecommunications authorities, TVOntario, Radio-Québec, the Saskatchewan Communications Network (SCN), Northern Canada Television and ACCESS Alberta were using broadcast television and, in some cases, other technologies to provide educational programming for learners of all ages. In 1987 Contact North/Contact Nord was set up by the Ontario government to facilitate access to all formal levels of education to northern Ontario residents. It did this through an audiographic network that serves numerous community learning centres. Other networks were established in Nova Scotia, New Brunswick, Manitoba, Saskatchewan, the Franco-Ontarian Network in Ontario, and CANAL in Québec. These varied in infrastructure from the use of satellite or microwave to broadcast video programming in Saskatchewan and Manitoba to the use of telephone lines for audio, audiographic and video-conferencing in New Brunswick and Nova Scotia. All of the networks adopted a flexible approach to technology that is consistent with learner needs and financial resources.

In the 1990s, the development and widespread use of the Internet had a major influence on the provision of distance education. Learners had ready access to enormous information sources, to conversations with other learners and experts in the field, and resources far beyond those of any single institution. Universities, colleges and technical institutes all sought to reach their learners 


\section{Інноватика у вихованні. Випуск 13.Том 1. 2021.}

through use of computer conferencing and subsequently learning management systems. Today, most universities and colleges offer distance learning and blended learning options to their students. Universities moved to provide online learning at first through computer conferencing and then using learning management systems. Colleges formed provincial consortia to share the costs of development and provision and aid innovation. The earliest, OntarioLearn (1995) has pooled resources from 24 colleges to become the largest college-level course provider in North America. Others were Campus Manitoba (1998), BCcampus (2002) and eCampus Alberta (2003). These organizations often host the colleges' Internet provider, offer course development assistance, provide single-source access and do extensive marketing.

It is estimated that each year at least a million people in Canada study through distance education from those unable to attend an institution, such as students confined to hospitals and persons with disabilities, to those who choose to or for whom it is necessary to study independently, e.g., working adults. Programs and courses are available from primary schooling to post-secondary education, with many more offerings that are noncredit. Many government departments and over $40 \%$ of large companies in Canada are already using some form of distance education. Commercial suppliers, as well as industrial, trade and professional organizations, are also providing distance learning courses and resources.

Nowadays, the Internet has become the major technology for distance education and its immediacy has placed greater emphasis on online learning as the major mode for distance education. The rationale for online learning has moved from access to flexibility and is increasingly driven by student demand and technology developments. One such is mobility with more people now accessing the Internet by mobile (phones, laptops, iPads, tablets) than by desk computers. Another trend is openness. Open Educational Resources (OERs) are essentially content and resources, including course materials and e-texts, available for use under a Creative Commons license. Massive Open Online Courses (MOOCs) provide free and open access to course content. Sites like YouTube and iTunes $U$ provide ready access to video resources, and online gaming has created new designs for learning.

Because learners have immediate access to online resources they have moved increasingly to just-in-time learning through short courses or modules. Providers range from professional associations and academic publishers to newspapers and fashion houses. Social media technologies (blogs, wikis, Twitter, Facebook) provide access to learning through interaction with others.

New forms of assessment include learning analytics and prior learning assessment reviews (PLAR). Analytics provide learners and instructors with feedback on progress while learning while PLAR provides an evaluation of various learning opportunities against a formal credential such as a degree. All these trends will impact online learning (Haughey, 2013).

Present-day distance learning is influenced a lot by computer and electronics technology. The technology has now made it possible for the guide 


\section{Інноватика у вихованні. Випуск 13.Том 1. 2021.}

and student to connect almost immediately. Study resources can be delivered instantly through computers, satellites, the internet, cable television, interactive video, etc.

Generally, Canadian provincial governments, Ministers of Education take adequate measures for online learning in pandemic conditions like the other countries of the world. These measures are based mainly on offering various distance and online learning programs for each educational level.

As part of the Government of Ontario's aim to build up and improve the Learn at Home program, the government working with non-profits, organizations, and businesses, is offering a comprehensive suite of services and resources to Ontario school boards to support students, parents and educators during the current school closure. School boards have asked for access to services, tools, and technology that can aid them in the delivery of modern and quality online learning.

The government launched the Ontario Together portal to solicit offers and encourage private enterprise and the non-profit sectors to step forward to propose solutions that historically have impeded learning from home. As a result of those submissions, Ontario is moving forward with 34 partnerships with organizations and private businesses, along with school boards, to address key needs among educators, students and their families during the COVID-19 outbreak. The government remains committed to an inclusive online learning program that enables local school boards to provide access to the technology and software required to learn from home.

Through the government's Broadband Modernization Program, the province is also working with all school boards to deliver sustainable, modernized networks with improved Internet access at the target speed. Upon completion, all students are expected to have the same equitable access to digital resources across the province.

Conclusions and further research prospects. We may not be able to go back to teaching and learning in the same ways as we did before COVID-19 or to provide the same types of environments and activities as we can implement in a classroom.

Online teaching requires various tasks to be accomplished in the different phases of planning, implementation, and reflection. Critical thinking, creativity, collaboration, and communication are always required no matter whether the class is taught online or offline.

The rapid spread of COVID-19 has demonstrated the importance of building resilience to face various threats, from pandemic disease to extremist violence to climate insecurity, and even, rapid technological change. The pandemic is also an opportunity to remind ourselves of the skills students need in this unpredictable world such as informed decision making, creative problem solving, and perhaps above all, adaptability. To ensure those skills remain a priority for all students, resilience must be built into our educational system.

Distance learning requires that the institution provide appropriate structures for the development of distance learning materials; the facilitation of learning 


\section{Інноватика у вихованні. Випуск 13.Том 1. 2021.}

such as opportunities for interaction with instructor and other learners; organizational procedures geared to the distance learner; adequate library services; and specific student support. To be successful such systems require sustained funding and organizational policies that do not marginalize distance education.

There are plenty of online tools available which is important for an effective and efficient learning environment and can help in creating a collaborative and interactive feedback learning where students can give their immediate feedback, ask queries and learn interestingly.

The benefits of online distance learning:

students learn most of their units as they would in a traditional class set up with the same curriculum;

the online classes, especially with the current pandemic, gives students the flexibility to interact with family and their pets during free periods;

online distance learning will also give parents a chance to engage and understand more about the various courses their children are taking.

Online distance learning is a wonderful opportunity and solution for students during these unprecedented times. Many students are concerned about interaction with other students, physical activities on campus and the quality of education.

\section{REFERENCES}

UNESCO. (2021). Education: From disruption to recovery. URL: https://en.unesco.org/covid19/educationresponse. [Accessed 20.03.21].

Hrastinski, S. (2008). Asynchronous and Synchronous E-Learning. EDUCAUSE. URL: https://er.educause.edu/articles/2008/11/asynchronousand-synchronous-elearning. [Accessed 23.03.21].

Moore, J., Dickson-Deane, C. and Galyen, K. (2011). E-Learning, online learning, and distance learning environments: Are they the same?. The Internet and Higher Education, 14(2). PP.129-135.

Singh, V. and Thurman, A. (2019). How Many Ways Can We Define Online Learning? A Systematic Literature Review of Definitions of Online Learning (1988-2018). American Journal of Distance Education, 33(4), PP.289306.

Berg, G. and Simonson, M. (2016). Distance learning | education. [online] Encyclopedia Britannica. URL: https://www.britannica.com/topic/distancelearning. [Accessed 23.03.21].

Klein, A. (2016). The Every Student Succeeds Act: An ESSA Overview. [online] Education Week. URL: https://www.edweek.org/policy-politics/theevery-student-succeeds-act-an-essa-overview/2016/03 [Accessed 23.03.21].

Haughey, M. (2013). Distance Learning. Thecanadianencyclopedia.ca. URL: https://www.thecanadianencyclopedia. ca/en/article/distance-learning. [Accessed 23.03.21].

Cook, D. \& Dupras, D. (2004). A practical guide to developing effective web-based learning. Journal of General Internal Medicine, 19(6). PP.698-707. 


\section{Інноватика у вихованні. Випуск 13.Том 1. 2021.}

Daniel, S.J. (2020). Education and the COVID-19 pandemic. Prospects, 49(1-2). PP.91-96.

Canadaeducation.info (2021). Distance Education- An Overview in Canada, What is Distance Education in Canada. URL: https://www.canadaeducation.info/distance-education. [Accessed 10.03.21].

Friedman, J. (2020). Tackle Challenges of Online Classes Due to COVID19. URL: https://www.usnews.com/education/best-colleges/articles/how-toovercome-challenges-of-online-classes-due-to-coronavirus. [Accessed 10.03.21].

Office of the Premier (2020). Government Supports Online Learning During COVID-19 Outbreak. News.ontario.ca. URL: https://news.ontario.ca/en/backgrounder/56973/government-supports-onlinelearning-during-covid-19-outbreak. [Accessed 25.03.21].

Armstrong-Mensah, E., Ramsey-White, K., Yankey, B. and Self-Brown, S., 2020. COVID-19 and Distance Learning: Effects on Georgia State University School of Public Health Students. Frontiers in Public Health, 8. doi:10.3389/fpubh.2020.576227.

Li, C. \& Lalani, F. (2020). The COVID-19 pandemic has changed education forever. This is how. World Economic Forum. URL: https://www.weforum.org/agenda/2020/04/coronavirus-education-globalcovid19-online-digital-learning/ [Accessed 21 March 2021].

Mohamed, G. (2020). Online Distance Learning in Canada and the United States. URL: https://studyinamerica.ke/2020/05/05/online-distance-learning-incanada-and-the-united-states/ [Accessed 27.02.20]. 


\title{
ДИСТАНЦІЙНА ОСВІТА В КАНАДІ: ЗАПОЧАТКУВАННЯ, РАННI ТА НОВІ ЗДОБУТКИ
}

\author{
Федоришин Олександр \\ кандидат педагогічних наук, \\ професор кафедри практики англійської мови \\ Рівненського державного гуманітарного університету, \\ м. Рівне, Україна \\ ORCID: 0000-0003-0731-0186 \\ e-mail: ofedoryshin@gmail.com \\ Федоришина Вікторія \\ фахівець білінгвального реєстру, \\ департамент $з$ акредитації закладів освіти, \\ м. Онтаріо, Канада \\ ORCID: 0000-0001-7303-6926 \\ e-mail:vfedoryshyna@oct.ca
}

Анотація. Увага зосереджена на найактуальнішій проблемі сьогодення - пандемії, яка спричинила вплив на світову систему освіти i призвела до майже тотального закриття закладів освіти усіх рівнів. Форма дистанційного навчання не $є$ новою і використовується вже досить давно, але через сучасні виклики вона потребує перегляду і нових підходів. Адже саме дистанційне навчання в умовах пандемії стає найпоширенішим методом у сфері освіти. Уряди багатьох країн приймають відповідні заходи 3 метою зниження рівня поширення коронавірусу та вимагають суворого дотримання правил соціальної дистанції та самоізоляції.

В освіті пандемія призвела до відходу від традиційних методів навчання і загострила увагу на дистанційних формах роботи. Головне завдання полягає у задіянні таких форм як комунікаційні технології для зв'язку учня з вчителем та іншими учнями. У статті розглядається стан освіти у Канаді (провінції Онтаріо). Заходи, які застосовує країна, тотожні із заходами інших країн, але акцент робиться на розробці і впровадженні як урядових, так і освітянських програм для кожного окремого рівня та їхній взаємодії між навчальними закладами, учнями та їх батьками.

Уряд тісно співпрацюе 3 різними організаціями (урядовими i неурядовими), намагаючись забезпечити навчальні закладами усім необхідним для дистанційного навчання, перш за все доступом до сучасних технологій та інтернету.

Ключові слова: пандемія COVID-19, соціальна дистанція, дистанційна освіта, самоізоляція, навчання в Інтернеті, апаратне забезпечення, програмне забезпечення, очні заняття, навчальне середовище.

Стаття надійшла до редакиіï 06.05.2021 p. 